\title{
Studies on Genetic Variation within Old Polish Cultivars of Common Oat
}

\author{
M. BOCZKOWSKA*, M. HARASIMIUK and A. ONYŚK \\ Plant Breeding and Acclimatization Institute (IHAR) - National Research Institute, Radzików, Poland \\ (Received 30 January 2014; Accepted 29 April 2014; \\ Communicated by M. Molnár-Láng)
}

\begin{abstract}
The gene pool of Polish oat cultivars is quite narrow. Obsolete cultivars bred at the beginning of the $20^{\text {th }}$ century could be one of the "new" sources of genetic diversity. Re-using them in breeding programs might be much easier than interspecific hybridization with wild relatives. The aim of this study was to assess genetic variation within cultivars bred in Poland before 1939. Molecular analysis was carried out using ISSR markers. The obtained results have shown the old cultivars are much more heterogenic than the advanced ones. Distinctiveness of the gene pool of these accessions in relation to the modern Polish cultivar and landrace was also observed. UPGMA analysis has shown, despite the considerable time lapse, the tested cultivars retain their genetic integrity. Based on archive pedigree data it was found that most of the analysed accessions had diverse origin. Low value of total genetic variation of the old cultivars collection may indicate the gene pool of the primeval oat forms which were brought and grown in Poland was quite narrow. Both breeding history and the results presented in this paper suggest the restoration of old cultivars to Polish breeding should be one of the main tasks of gene bank in the future. According to the monitoring of accession sharing conducted by the national gene bank, breeders' interest in old cultivars and landraces was and still is neglected.
\end{abstract}

Keywords: common oat, ISSR, genetic variation

\section{Introduction}

Modern breeding in major is based on continuous, strict selection among progeny of crosses of related, current or recent cultivars. New cultivars with higher yield, pathogens resistance and better adaptation to particular farming conditions, which are still introduced into market, are homogeneous or almost homogeneous populations. Popularization of this type of breeding in the last decades increased genetic erosion of crop gene pools (Gepts 2006). Year by year landraces and old cultivars were replaced by newly bred advanced ones. In many cases gene banks collections are the only place where landraces and old cultivars survived. Unfortunately, the understanding of necessity of genetic diversity protection came after the vast majority of these obsolete materials were irreversibly lost. Nowadays, in the face of lack of crop diversity old cultivars have become the treasure.

*Corresponding author; E-mail: maja.boczkowska@gmail.com 
They were bred before widespread use of fertilizers, pesticides or irrigation and therefore they could own some adaptation traits which were accidentally removed during subsequent breeding (Frankel et al. 1995). In Poland, before the 1939, around 60 cultivars of common oat (Avena sativa L.) were bred.

During World War II Polish oat breeding programs were totally destructed. After the war, as a compensation for the destroyed breeding centres and breeding material, German cultivars were introduced to Poland, which later became the basis for further breeding programs (Świerczewski and Mazaraki 1993). In subsequent decades the materials with diverse origins from all over Europe were used in Polish breeding (Nowosielska 2006). Today, obsolete cultivars from different countries form the core of common oat collection in Polish national repository (71\%). However, out of around 160 accessions with Polish cultivar status only 23 were bred before 1939. Study of the genetic diversity of this group of old cultivars became essential, because of the history of Polish breeding, most of them had never been used to create new cultivars.

The major aim of the study was to evaluate the genetic diversity within old common oat cultivars, which were bred in Poland before 1939, i.e. before the World War II. This was a direct continuation of the assessment of genetic and morphological diversity of common oat cultivars bred in Poland in the twentieth century (Nowosielska 2006; Boczkowska et al. 2014). This is also a part of major project that will describe the genetic variation of the whole Avena collection in Polish national repository.

\section{Materials and Methods}

In this study 23 cultivars of common oat, which were bred and cultivated in Poland before 1939, were analysed. All detailed information about the tested collection was placed in Table 1. Modern cultivar Krezus and Polish landrace PL50556 were used as a reference material. All accessions came from the collection of the National Centre for Plant Genetic Resources in Radzików, Poland. Each accession was represented by 24 individuals. Molecular analyses were performed using ISSR markers and were carried out according to the protocols described by Boczkowska and Tarczyk (2013). In order to estimate the genetic variation within each cultivar the Nei's coefficient (Lynch and Milligan 1994) was calculated. Pair-wise Fst values were estimated among accessions using AFPL-SURV 1.0 (Vekemans et al. 2002). Based on genetic distance matrix (Nei 1978) multidimensional scaling PCoA (Principal Coordinate Analysis) and Unweighted Pair Group Method with Arithmetic Mean (UPGMA) were carried out. Analysis of molecular variance (AMOVA) was also performed (Excoffier et al. 1992). All analyses were performed using the software FAMD 1.25 (Schlüter and Harris 2006), GenAlex 6.5 (Peakall and Smouse 2012) and TreeView 1.6.6 (Page 1996).

\section{Results}

The level of genetic diversity within accessions was estimated on the basis of Nei's variation coefficients $(\mathrm{Hj})$ and ranged 0.06 (Krezus) - 0.29 (PL50556). In the group of old 
Table 1. List of analysed early cultivars and reference samples with some basic information

\begin{tabular}{|c|c|c|c|c|}
\hline $\begin{array}{l}\text { Breeding } \\
\text { period }\end{array}$ & $\begin{array}{l}\text { Cultivar } \\
\text { name }\end{array}$ & $\begin{array}{c}\text { Accession } \\
\text { number }\end{array}$ & Pedigree & $\begin{array}{l}\text { Study } \\
\text { number }\end{array}$ \\
\hline & Biały Mazur & PL51466 & landrace $\times$ Biały Orzeł & 2 \\
\hline & Lubelski & PL51166 & no data & 8 \\
\hline \multirow[t]{12}{*}{ Before 1914} & Niemierczański & PL51084 & selection of landrace from Podole & 9 \\
\hline & Najwcześniejszy & & & \\
\hline & Ozimowy & PL51087 & no data & 10 \\
\hline & Sobieszyński & PL51261 & selection of Rychlik Lubelski & 17 \\
\hline & Teodozja & PL50976 & selection of Scottish oat & 20 \\
\hline & Antoniński Żółty & PL51902 & selection of Żółty Lochowa & 1 \\
\hline & Duppawski & PL51167 & selection of landrace from Czech & 3 \\
\hline & Grzywacz Późny Wołyński & PL 50788 & selection of Marczak Włościański & 4 \\
\hline & Jagiełło & PL51507 & selection of Rychlik Mikulicki & 5 \\
\hline & Kanarek Mikulicki & PL51510 & selection of Jagiełło & 6 \\
\hline & Kościelecki & PL50334 & selection of Marczak Włościański & 7 \\
\hline & Podkowa Dłużewski & PL51227 & selection of Leutewicki & 11 \\
\hline \multirow[t]{11}{*}{ 1918-1939 } & Puławski Średniowczesny & PL50406 & selection of Pfiffelbacher Gelb & 12 \\
\hline & Puławski Wczesny & PL51232 & selection of landrace from Siedleckie & 13 \\
\hline & Rychlik Kozarowski & PL51237 & selection of landrace from Kozarowszczyzna & 14 \\
\hline & Rychlik Oberek & PL51233 & Rychlik Podgórski $\times$ Iogold & 15 \\
\hline & Rychlik Trybański & PL51235 & selection of Złoty Rychlik Lubelski & 16 \\
\hline & Sołacki Wczesny & PL50581 & selection of landrace from Sandomierszczyzna & 18 \\
\hline & Tatrzański & PL50975 & selection of landrace from Podhale & 19 \\
\hline & Udycz Biały & PL51051 & Kanarek Mikulicki × Zwycięzca (from & \\
\hline & & & Niemierczański Najwcześniejszy) & 21 \\
\hline & Udycz Żółty & PL51050 & Żółty Pfluga × Żółty Lochowa & 22 \\
\hline & Zielony & PL50869 & selection of landrace from Wołyń & 23 \\
\hline \multirow[t]{2}{*}{ 2005-today } & Krezus & & $\begin{array}{l}\text { Góral } \times((\text { Flamingsnova } \times \text { Swan mut. }) \\
\times \text { Dukat }))\end{array}$ & 24 \\
\hline & landrace & PL50556 & collected in 1978 at $4930 \mathrm{~N} 2014 \mathrm{E}$ & 25 \\
\hline
\end{tabular}

cultivars it ranged from 0.12 (Jagiełło) to 0.20 (Kościelecki). For more details please see Fig. 1. The total genetic diversity was 0.146 and in two breeding periods was equal to 0.14 for the cultivars bred before 1914 and 0.15 for the ones bred between 1918 and 1939 .

The average value of pair-wise fixation index (Fst) was 0.586. Its range was from 0.284 (Udycz Biały vs. Puławski Średniowczesny) to 0.907 (Krezus vs Jagiełło). The mean Fst in the group of old cultivars was 0.565 and it ranged 0.284-0.750 (Udycz Biały vs. Puławski Średniowczesny; Grzywacz Późny Wołyński vs. Zielony).

The genetic distance ranged from 0.022 (Puławski Średniowczesny vs Udycz Biały) to 0.386 (Krezus vs Rychlik Oberek). The maximum genetic distance among old cultivars was 0.137 (Grzywacz Późny Wołyński vs Zielony).

In order to implement hierarchical AMOVA, the tested accessions were divided into four groups: bred before 1914, bred in the period 1918-1939, the modern cultivar and landrace. The analysis showed that $27 \%$ of the variance was detected within the acces- 


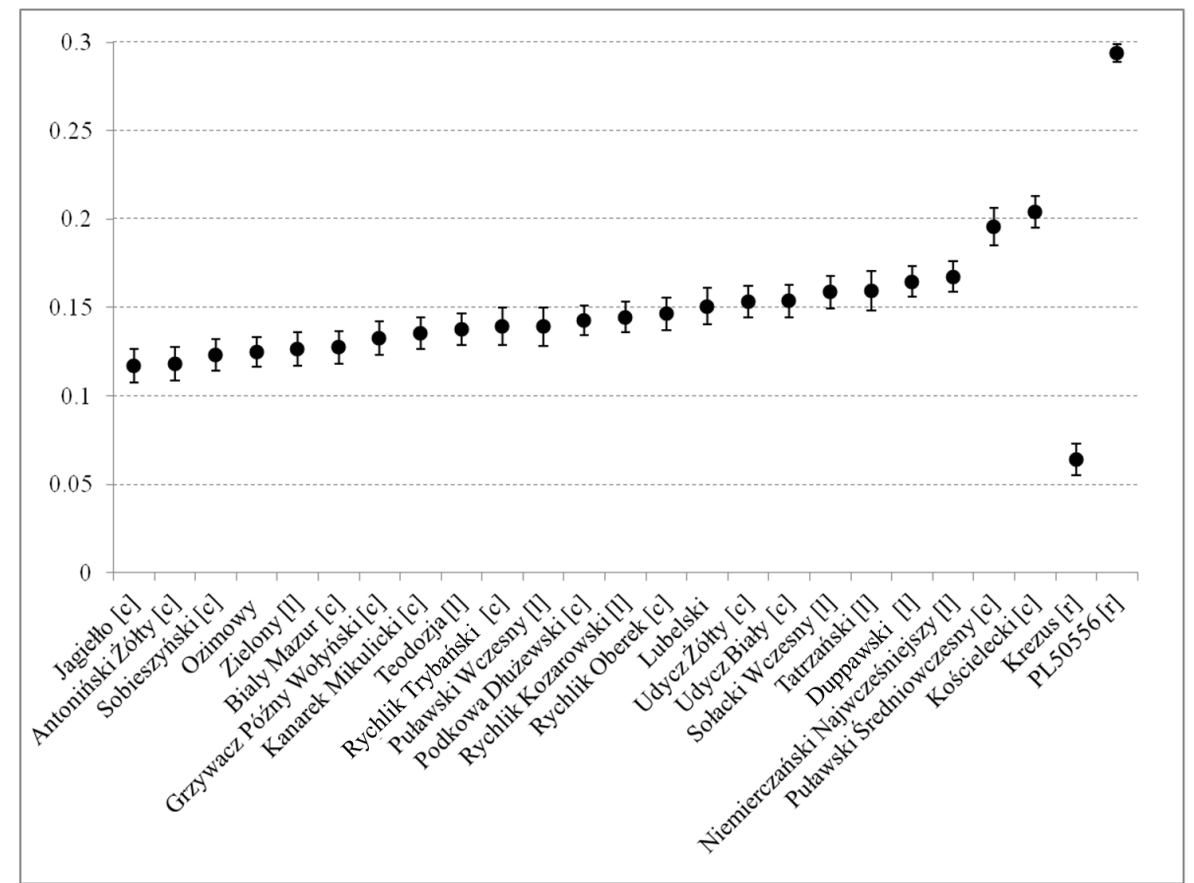

Figure 1. Nei (Hj) genetic diversity coefficient values within each tested accession. [c] - bred from cultivar, $[1]$ - bred from landrace, $[\mathrm{r}]$ - reference sample

sions, 38\% among them and 34\% among the groups. However, to determine the level of variation within a collection of old cultivars, re-analysis of molecular variance was performed on two groups and again as allocation criterion breeding period (before 1914 and 1918-1939) was used. This time AMOVA showed that $38 \%$ of the variance was detected within the cultivars, $61 \%$ occurred among them and only $1 \%$ between breeding periods.

The UPGMA dendrogram (Fig. 2) showed two major clusters composed of 12 and 10 old cultivars, respectively. Three accessions with lower affinity were also identified (Grzywacz Późny Wołyński, Krezus and landrace 50556). All of the tested individuals were grouped into separate sub-clusters corresponding to the analysed accessions without any mismatch.

The first three principal coordinates of PCoA explained in total $74.47 \%$ of variation (respectively $42.30 \%, 19.97 \%$ and $12.20 \%$ ). Bi-plots of the first vs. second coordinate (Fig. 3a) showed significant genetic distinctness of Krezus, as well as second reference landrace PL50556. In this plot the whole collection of old cultivars was placed together, which stays in accordance with general value of genetic diversity coefficients and the AMOVA results. For better understanding of old cultivars diversity analysis of principal coordinates was carried out based on pair-wise population genetic distance (Fig. 3b). This plot showed also some distinctiveness of Zielony cultivar. 


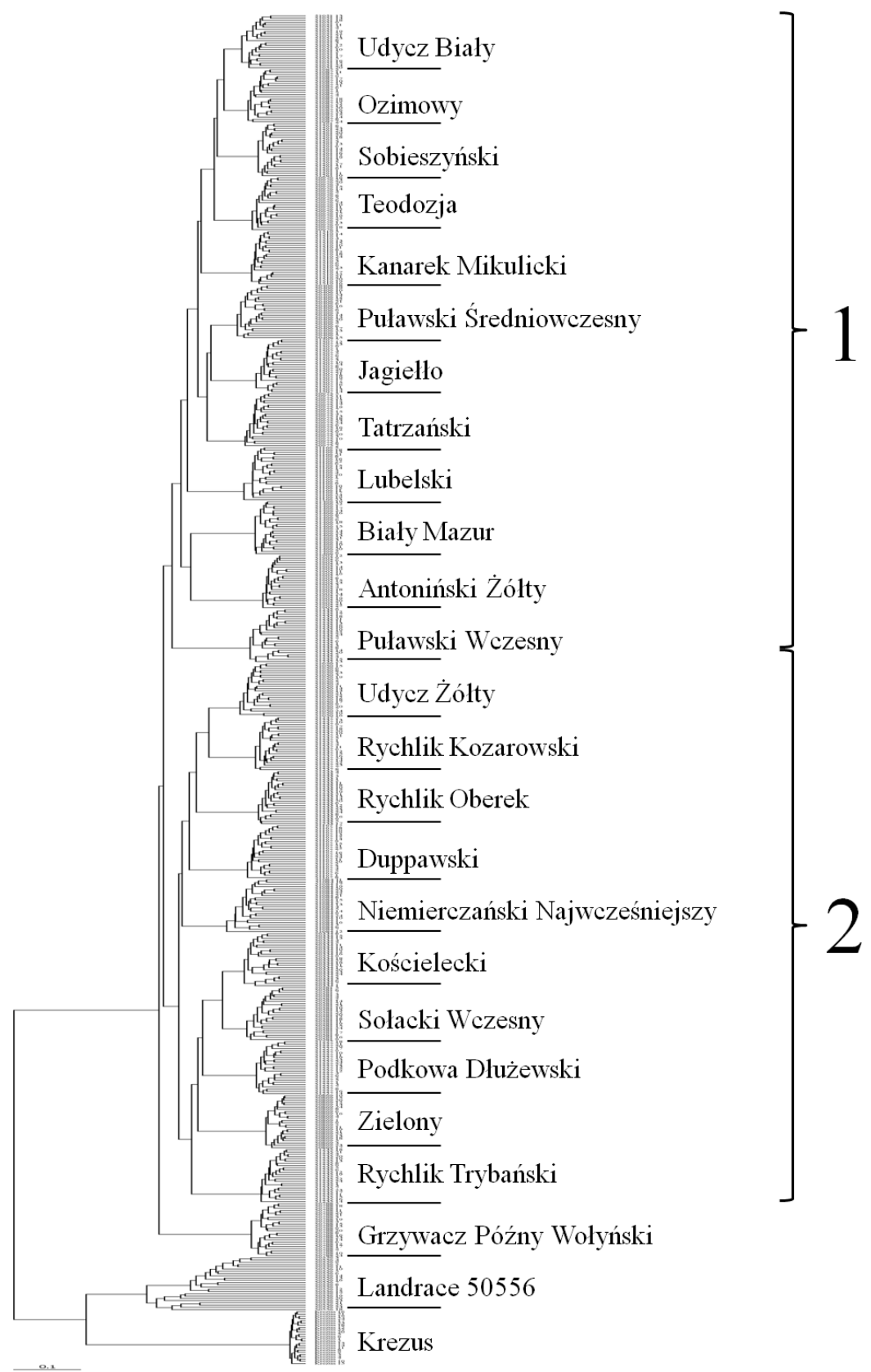

Figure 2. Dendrogram clustering 23 Polish early oat cultivars and two reference accessions based on the Nei distance. Main clusters were marked with numbers 

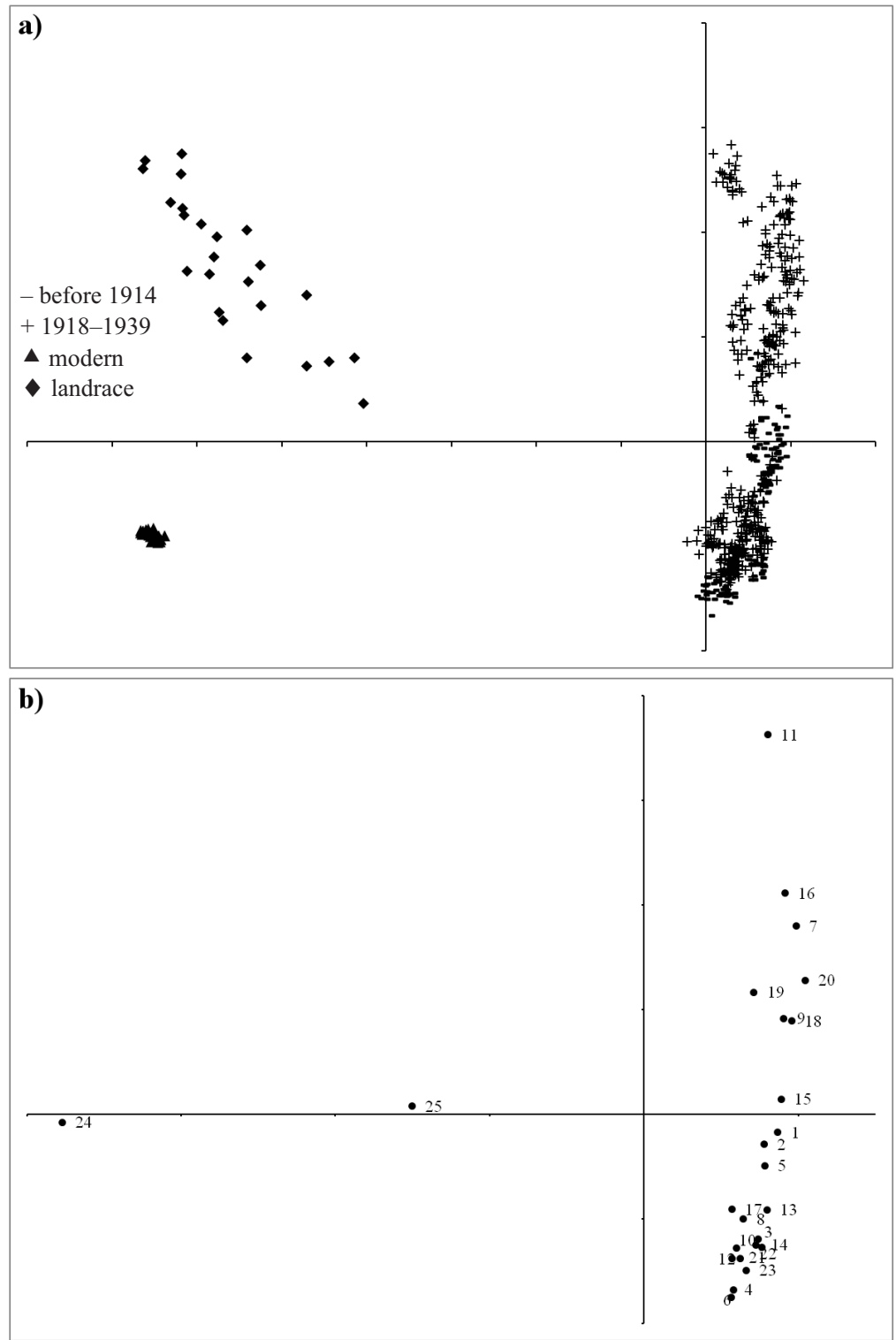

Figure 3. Biplot of PCoA analysis results. a - for the whole data set, $\mathrm{b}$ - based on pair-wise population genetic distance: 1 - Antoniński Żółty, 2 - Biały Mazur, 3 - Duppawski, 4 - Grzywacz Późny Wołyński, 5 - Jagiełło, 6 - Kanarek Mikulicki, 7 - Kościelecki, 8 - Lubelski, 9 - Niemierczański Najwcześniejszy, 10 - Ozimowy, 11 - Podkowa Dłużewski, 12 - Puławski Średniowczesny, 13 - Puławski Wczesny,

14 - Rychlik Kozarowski, 15 - Rychlik Oberek, 16 - Rychlik Trybański, 17 - Sobieszyński, 18 - Sołacki Wczesny, 19 - Tatrzański, 20 - Teodozja, 21 - Udycz Biały, 22 - Udycz Żółty, 23 - Zielony, 24 - Krezus, 25 - landrace PL50556 


\section{Discussion}

Currently, it is considered that breeding progress which took place in the twentieth century, resulted in a dramatic reduction of crops' genetic diversity (Gepts 2006). A meta-analysis of crop cultivars showed the largest decrease of genetic diversity occurred in the 1960s. It was also noted that in the next decades, variation gradually increased, until the 90s, when it reached the level equal with that in the 30s (van de Wouw et al. 2010). This study was focused on estimating diversity within the collection of the Polish cultivars which were bred until 1939. The genetic variation among individuals of particular cultivars was especially in the range of our interests. Such an analysis brings undoubted benefits of knowledge about the degree of internal diversity and population structure, however, entails considerable financial outlay because it requires sufficiently large testing representative samples of individuals. Therefore, little information is available about the diversity within cultivars. Modern cultivars are genetically homogeneous so there is no need to conduct such studies. In case of old cultivars their genetic background could be more complex.

In this study the level of genetic diversity within particular accessions was estimated on the basis of Nei's variation coefficients. In the group of old cultivars Kościelecki appeared to be the most heterogeneous, whereas Jagiełło was identified as the most homogeneous one. The level of heterogeneity of the tested materials was significantly higher in comparison with the modern Polish oat cultivar Krezus. It was also higher than observed within durum wheat cultivars $(\mathrm{Hj}=0.02-0.09)$ (Soleimani et al. 2002). However, the values of genetic diversity coefficients were much lower than those obtained for oat landrace PL50556. Similar levels of diversity were obtained for Scandinavian landraces of oat $(\mathrm{Hj}$ $=0.18-0.61)$ and barley $(\mathrm{Hj}=0.07-0.53)$ (Hagenblad et al. 2011). For comparison, in cross-pollinating rye landraces this ratio had a value of 0.44-0.64 (Hagenblad et al. 2011). AFLP analysis of Canadian durum wheat cultivars showed that the cultivars, which had been bred from landraces were characterized by higher heterogeneity than those derived from commercial cultivars (Soleimani et al. 2002). In the presented studies such a difference has not been noticed (Fig. 1). The analysis showed also that accessions from the period 1918-1939 were characterized by a higher genetic diversity than the group of six cultivars bred before 1914. The difference could result from lower number of cultivars from an earlier period which have survived till today. Analogous results were obtained during the evaluation of morphological differentiation of these materials (Boczkowska et al. 2014). The values of diversity coefficients clearly indicated that the old cultivars were undoubtedly formed by breeding programs, but criteria were not as stringent as those used in modern breeding. Higher heterogeneity of old materials may be associated both with different breeding criteria at the beginning of the twentieth century, as well as with the appearance of contaminations during few decades that had passed until seeds storage in the gene bank. Despite the heterogeneity of the studied cultivars, they retained their integrity. This was indicated by high value of the pair-wise Fst coefficient and UPGMA dendrogram, so the thesis of the material contamination could be definitely rejected. The 
dendrogram also indicated the set of ISSR markers was sufficient for molecular identification of all tested accessions.

The hierarchical AMOVA showed that the most of variance occurred among the old cultivars and what is more interesting there was almost no difference in genetic variation between the two historical periods (before 1914 and 1918-1939). Based on Nei's variation coefficient for these two breeding periods, and the AMOVA values it could be assumed that this two gene pools are largely common.

Several independent studies of genetic diversity of oat germplasm collections indicated that the gene pool of common oat is relatively narrow (Fu et al. 2003, 2005; Leišova et al. 2007; Achleitner et al. 2008). The extraordinary low level of genetic diversity was found among cultivars bred in Europe (Achleitner et al. 2008). The results obtained for the Polish old cultivars stay in accordance with the literature. A low value of maximum genetic distance among cultivars as well as low value of variation coefficients could indicate that the gene pool of oats bred on Polish territory before 1939 was rather narrow. Analysis of the archive pedigrees data demonstrated that most of the studied cultivars had different origins. This might indicate a relatively small variation of the primeval oat forms that were brought and grown in Poland. This thesis is compatible with the results of diversity analysis of Polish landraces by ISSRs (Boczkowska and Tarczyk 2013) and AFLPs (Nowosielska 2006) and also previous studies of 64 oat cultivars bred in Poland in the twentieth century by AFLPs, RAPDs and morphology (Nowosielska 2006). Contemporary Polish cultivars are characterized by even lower level of genetic differentiation (Paczos-Grzęda 2007), than the set of old ones tested in this study. Looking at all results obtained so far for genetic diversity of Polish oat cultivars, it could be concluded that the variation level is low and it is independent of the breeding period. However, very interesting result was obtained for the modern cultivar Krezus, which was used in this study as a reference sample, it exhibited significant genetic distinctness from the whole collection of old cultivars (Fig. 3a). Its genetic pool was based on the Austrian cultivar Swan. This might suggest that the gene pools of modern and old cultivars are substantially different. It could be also a confirmation that the old cultivars may be useful for gene pool expanding in breeding. However, it is necessary to determine the degree of similarity of these two gene pools by comparative analysis. Based on the PCoA scatter-plot there was no significant difference in genetic distinctiveness between cultivars with foreign and national pedigree. Similar results were presented for the Canadian oat cultivars bred in the $1930 \mathrm{~s}$ (Fu et al. 2003). At the same time the distinctiveness of Zielony cultivar was observed. Interestingly, only this cultivar was classified as a mixture of obtusata Alef. and tartarica Ard. botanical varieties (Boczkowska et al. 2014).

The obtained results of ISSR analysis of 23 old oat cultivars showed relatively high level of similarity to pedigree data. Both PCoA plot (Fig. 3b) and UPGMA dendrogram (Fig. 2) clearly showed the proximity of three cultivars: Jagiełło, Kanarek Mikulicki and Udycz Biały. They had a common path of breeding. Kanarek Mikulicki was selected from Jagiełło, and then became the parent for Udycz Biały. At the same time it could be observed that a common origin was not always reflected in the genetic similarity. Grzywacz Późny Wołyński and Kościelecki were obtained through selection from Marczak 
Włościański cultivar but the breeding process took place in two different centres (data not shown). These two cultivars were grouped into distinct clusters, had different levels of homogeneity (Fig. 1) and, what is more important, they represented completely different phenotypes. Plants belonging to Kościelecki cultivar had white lemma colour, equilateral type of panicle while Grzywacz Późny Wołyński had yellow colour of lemma and unilateral panicle (Boczkowska et al. 2014).

Old cultivars, like landraces, could be a good possible source of diversity for contemporary breeding. Re-using them in breeding programs might be much easier than interspecific hybridization with wild relatives. The results presented in this paper showed that Polish old cultivars have distinctive gene pool from modern cultivars. Their use could result in an extension of the gene pool of Polish cultivars. According to the monitoring of accession sharing conducted by the national gene bank, maintained by National Centre of Plant Genetic Resources in The Plant Breeding and Acclimatization Institute - National Research Institute, breeders' interest in old cultivars and landraces was and still is neglected. The restoration of these accessions to Polish breeding should be one of the main tasks of gene bank for the next future.

\section{Acknowledgements}

The authors would like to express their utmost gratitude to Zofia Bulińska-Radomska, head of National Centre for Plant Genetic Resources, IHAR-PIB, who created the capacity to perform the research presented in this paper. The warmest thanks to Bogusław Lapiński and Wiesław Podyma, for their constructive remarks during preparation of this manuscript and to Elżbieta Tarczyk, for her irreplaceable help during plant material preparation. In memory of Janina Dunińska, without whose mental support this study would have been much more difficult.

\section{References}

Achleitner, A., Tinker, N., Zechner, E., Buerstmayr, H. 2008. Genetic diversity among oat varieties of worldwide origin and associations of AFLP markers with quantitative traits. Theor. Appl. Genet. 117:1041-1053.

Boczkowska, M., Tarczyk, E. 2013. Genetic diversity among Polish landraces of common oat (Avena sativa L.). Genet. Resour. Crop Evol. 60:2157-2169.

Boczkowska, M., Nowosielski, J., Nowosielska, D., Podyma, W. 2014. Assessing genetic diversity in 23 early Polish oat cultivars based on molecular and morphological studies. Genet. Resour. Crop Evol. doi: 10.1007/s10722-014-0087-4.

Excoffier, L., Smouse, P., Quattro, J. 1992. Analysis of molecular variance inferred from metric distances among DNA haplotypes: Application to human mitochondrial DNA restriction data. Genet. 131:479-491.

Frankel, O.H., Brown, A.H.D., Burdon, J.J. 1995. The Conservation of Plant Biodiversity. Cambridge University Press, $299 \mathrm{pp}$.

Fu, Y., Peterson, G., Williams, D., Richards, K., Fetch, J. 2005. Patterns of AFLP variation in a core subset of cultivated hexaploid oat germplasm. Theor. Appl. Genet. 111:530-539.

Fu, Y., Peterson, G., Scoles, G., Rossnagel, B., Schoen, D., Richards, K. 2003. Allelic diversity changes in 96 Canadian oat cultivars released from 1886 to 2001. Crop Sci. 43:1989-1995.

Gepts, P. 2006. Plant genetic resources conservation and utilization: The accomplishments and future of a societal insurance policy. Crop Sci. 46:2278-2292. 
Hagenblad, J., Zie, J., Leino, M.W. 2011. Exploring the population genetics of genebank and historical landrace varieties. Genet. Resour. Crop Evol. 59:1185-1199.

Leišova, L., Kučera, L., Dotlačil, L. 2007. Genetic resources of barley and oat characterised by microsatellites. Czech J. Genet. Plant Breed. 43:97-104.

Lynch, M., Milligan, B.G. 1994. Analysis of population genetic structure with RAPD markers. Mol. Ecol. 3:91-99.

Nei, M. 1978. Estimation of average heterozygosity and genetic distance from a small number of individuals. Genet. 89:583-590.

Nowosielska, D. 2006. Różnorodnośč genotypowa i morfologiczna odmian i populacji miejscowych owsa (Avena sativa L.) uprawianych w Polsce (Genotypic and morphological diversity of cultivars and landraces of oats (Avena sativa L.) cultivated in Poland). Ph.D. Thesis. Plant Breeding and Acclimatization Institute, Radzików, Poland. (in Polish)

Paczos-Grzęda, E. 2007. Wykorzystanie metod ISSR i RAPD oraz analizy rodowodów do oceny podobieństwa międzyodmianowego Avena sativa (Cultivars similarity estimation based on RAPD and ISSR methods and pedigree analysis). Zesz. Probl. Post. Nauk Rol. 517:547-558. (in Polish)

Page, R. 1996. TREEVIEW: An application to display phylogenetic trees on personal computers. Comput. Appl. Biosci. 12:357-358.

Peakall, R., Smouse, P.E. 2012. GenAlEx 6.5: Genetic analysis in Excel. Population Genetic Software for Teaching and Research - An update. Bioinforma. doi:10.1093/bioinformatics/bts460

Schlüter, P., Harris, S. 2006. Analysis of multilocus fingerprinting data sets containing missing data. Mol. Ecol. Notes 6:569-572.

Soleimani, V.D., Braum, B.R., Johnson, D.A. 2002. AFLP and pedigree-based genetic diversity estimates in modern cultivars of durum wheat [Triticum turgidum L. subsp. durum (Desf.) Husn.]. Theor. Appl. Genet. 104:350-357.

Świerczewski, A., Mazaraki, M. 1993. Hodowla owsa (Oat breeding). In: Mazurek, J., Wojcieska, U., Mazurek, J., Król, M. (eds), Biologia i agrotechnika owsa (Biology and Agrotechnology of Oats). IUNG, Puławy, Poland, pp. 129-161. (in Polish)

van de Wouw, M., van Hintum, T., Kik, C., van Treuren, R., Visser, B. 2010. Genetic diversity trends in twentieth century crop cultivars: A meta analysis. Theor. Appl. Genet. 120:1241-1252.

Vekemans, X., Beauwens, T., Lemaire, M., Roldan-Ruiz, I. 2002. Data from amplified fragment length polymorphism (AFLP) markers show indication of size homoplasy and of a relationship between degree of homoplasy and fragment size. Mol. Ecol. 11:139-151. 